\title{
Scholarship between the Lines: Interlinear Glossing in Siamese Literary Manuscripts
}

\begin{abstract}
This article explores the tradition of writing interlinear glosses in Siamese literary manuscripts dated to the late eighteenth and the nineteenth century. The glosses annotate archaic and obscure words found in texts transmitted from the kingdom of Ayutthaya and in texts adapted from foreign poetry, such as pieces of writing in Khmer and the Lan Na Tai language, reflecting an attempt by traditional scholars of the Bangkok period to comprehend these archaic and foreign literary texts. The glosses from each literary manuscript appear to have been added separately and are not identical. The only text which reflects the glossing tradition is Yuan Phai, an archaic royal eulogy from fifteenth-century Ayutthaya in which identical glosses can be found in multiple manuscripts. Furthermore, the glosses in Yuan Phai were also adopted and enhanced, eventually constituting a separate commentary of the text in the late nineteenth century. Although the number of glossed manuscripts that have survived is limited, the interlinear glosses in them reveal how literary texts were interpreted by traditional scholars and readers and should therefore be regarded as significant evidence of the study of Siamese literature and Siamese manuscript culture.
\end{abstract}

\section{Introduction}

Glossing between the lines, annotating obscure words and commenting on the main text are editorial activities that are not found very frequently in Siamese manuscripts. This is because learning in pre-modern Thailand was mainly based on oral traditions in which knowledge was transmitted directly from teachers to students. Therefore, students in old Siam tended to learn how to interpret literary texts in the presence of their teachers. However, in some cases involving old Thai literary pieces, which were supposedly considered obscure in terms of reading and interpretation, individual readers and users of manuscripts wrote glosses between the lines, providing the meaning of archaic words and sometimes explaining the meaning of a particular stanza. Interlinear glosses are generally unique to the manuscript in which they occur; only one case of archaic poetry

2 Open Access. () 2021 Peera Panarut, published by De Gruyter. (cc) BY-NC-ND This work is licensed under the Creative Commons Attribution-NonCommercial-NoDerivatives 4.0 International License.

https://doi.org/10.1515/9783110741124-011 
exhibiting a tradition of annotation has been found so far. This article explores interlinear glossing in Siamese manuscripts, its function and the key role it played in deciphering the meaning and significance of the old texts they contain, particular when approaching the texts from a modern viewpoint.

In this article, the words 'Siamese' and 'Thai' refer to the traditional culture of the central and southern regions of modern Thailand, which constitutes the country's national culture today. The Siamese or Thai belong to the south-western group of the Tai-Kadai ethno-linguistic family, whose ancestors migrated southwards from Southern China to mainland South-east Asia presumably in the ninth to twelfth centuries. ${ }^{1}$ These south-western Tai interacted with indigenous peoples living in mainland South-east Asia, most of whom were from an AustroAsiatic background, and gradually became influenced by their culture and religion, particularly that of the Khmer and the Mon. Literacy among the Tai is considered part of their Mon-Khmer legacy. Writing emerged among different groups of southern Tai-speaking people for the first time in the Sukhothai Kingdom in the upper part of the Chao Phraya river basin in Central Thailand. This occurred sometime around the late thirteenth century, based on the writing of the Khmer, who ruled over the area for many centuries. Around the same time, the neighbouring Siamese kingdom of Ayutthaya (1351-1767) in the lower parts of the Chao Phraya river basin adapted Sukhothai writing and developed it further over the centuries. When the Siamese capital of Ayutthaya was conquered by Burmese troops in 1767, the Siamese loyalists succeeded in re-establishing the defeated kingdom by moving the capital closer to the sea, first to Thonburi (1767-1782) and then to Bangkok on the opposite bank of the River Chao Phraya (from 1782 onwards). The restored Siamese kingdom at Thonburi and Bangkok was considered the successor state of Ayutthaya in terms of culture and political power and it actually became the most powerful kingdom in the Tai-speaking world in the nineteenth century.

Traditional manuscripts must have been used by the Siamese kingdom of Ayutthaya for many centuries, but we have not any evidence of an earlier date due to the limited durability of the writing material. The earliest extant manuscripts ${ }^{2}$ have been dated to the seventeenth century. The most common types of

1 The terms 'Siamese' and 'Thai' are often used as synonyms. In this sense, the term 'Thai' refers to the Thai-speaking population of central and southern Thailand, which is differentiated from the generic term 'Tai' referring to the larger ethno-linguistic family to which the Thai belong together with the Lao, Shan and many other smaller groups. For more details on the history of the early Tai, see Wyatt 2003 and Baker 2002.

2 The earliest Siamese palm-leaf manuscript has been dated to 1615, while the oldest extant khòi-paper manuscript is dated to 1680 (Kongkaew Weeraprachak 2010, 24, 38). 
traditional manuscripts are palm-leaf and khòi-paper leporello manuscripts. Roughly speaking, palm-leaf manuscripts are most frequently used for writing Buddhist texts in both canonical Pali and vernacular Thai, while khòi-paper leporello manuscripts are more often used for recording secular texts such as historical records, non-religious treatises and poetry. Khòi-paper manuscripts are made of a long piece of khòi paper produced from the bark of the khò tree (Streblus asper) and are folded in a leporello style. This article focuses mainly on the glossing of vernacular Siamese poetry, with khòi leporello manuscripts providing the main data.

Vernacular Siamese poetry plays an important role within the traditional system of Siamese education, both as a topic of study and as a medium for the transmission of other fields of knowledge. In the traditional education system, which by and large was housed within the monasteries, children who were mainly male were obliged to learn how to read poetry in simple verses as soon as they had acquired a grasp of basic orthography, as many different treatises or manuals (in Thai: tamra) on orthography were written in verse form. Furthermore, after mastering basic orthography, the students began working with a more advanced text - a key treatise called Cindamani (literally, 'Jewel of Thought') - in order to understand more sophisticated orthography and learn how to read and write advanced poetic metres as well. Cindamani contains examples of old poems in different verses cited from different texts. ${ }^{3}$ These citations of poetry were a topic for study and discussion among teachers and students for many generations. After their training on orthography and poetics, students were expected to be able to access a number of old literary pieces that had long been read and studied as poetic models, such as old epic and lyric poetry. In addition, some texts also had a specific function as didactic or ceremonial texts. Apart from the study of poetics, literate students began studying other fields of knowledge as well such as Buddhist education, mathematics, astrology, divination and medicine or began training in other skills and lore, ${ }^{4}$ which was necessary for occupations, trade or working as an official at the royal court. As treatises from some branches of knowledge are still written in a poetic form, knowledge about orthography and poetics has long been perceived as a precondition for acquiring further kinds of knowledge. ${ }^{5}$

It is worth noting here that orality also played a significant role in the traditional education of the Siamese. Although written treatises also appear in some

3 See Thawat Punnothok 1995, 43-58.

4 Wyatt 1969, 14-16.

5 Brun 1990, 44. 
fields of knowledge including orthography and poetics, treatises did not function as instructive manuals for autodidacts, but rather as a collection of lessons with formulas and lists of keywords; we rarely find treatises with thorough, comprehensive explanations. Students probably obtained further explanations orally from their teachers, while the treatise itself generally only records core knowledge. ${ }^{6}$ Even though literate students read and studied the pieces of poetry, we seldom have any evidence of how they actually interpreted the texts contained in the manuscripts.

Nevertheless, among the literary works which were read and studied by scholars in the Bangkok period, there are several cases in which annotations and commentaries on texts were provided as glosses between the lines of the main texts and sometimes in the blank margins of the manuscript 'page'. In these instances, the manuscripts not only served as carriers of texts, but as carriers of knowledge within the texts, which can rightly be perceived as part of traditional textual scholarship in pre-modern Siam. As traditional textual scholarship was mainly transmitted through an oral tradition, glosses between the lines provide significant evidence revealing how the text was read and interpreted.

\section{Interlinear writing in Siamese manuscript culture}

In manuscripts of Siamese poetry, the main text is often written in neat, uniform handwriting (Thai tua bancong) in which each written character can easily be recognised. Copying texts carefully in a neat hand takes some time, but it ensures that the texts will be accessible to any literate person in future. In contrast, scribbled handwriting (Thai tua wat) can be done quickly. Indeed, many scribes are likely to have suffered from a shortage of time when copying a text, and scribes also had to record what was dictated to them as quickly as they could. Scribbled handwriting cannot be read easily, so it is not the best way of producing a text for long-term use, unlike the more legible neat handwriting. In many cases, the principal text in Siamese poetry has therefore been written in a neat hand - one employed in most manuscripts, in fact. Additional writing was often added between the lines of the main text later on, sometimes in handwriting, style or content that differed from the main text. Different handwriting is often employed by modern scholars to differentiate interlinear writing added later from the principle text

6 See Brun 1990 for more details. 
written by the original scribe. It is noteworthy that interlinear writing in manuscripts of Siamese poetry is sometimes planned and written by the scribe himself, thus appearing in neat, uniform handwriting corresponding to that of the main text, although such cases are rather rare.

Most cases of interlinear writing found in Siamese manuscripts were intended as corrections of the main text, however, since the latter had been miscopied or certain words omitted. When making interlinear corrections, the scribe or reader would either cross out the mistake in the main text or mark it with a cross (+) and write the correct word above or below it. The example of an interlinear correction shown in Fig. 1 comes from a manuscript of Siamese poetry entitled Phra Suthon Kham Chan ('The Poem of the Tale of Sudhana Jataka') and shows the correction of an omitted letter, which has been written in a scribbled hand. In this case, the cross was inserted above the line, while the added letter was written beneath the line.

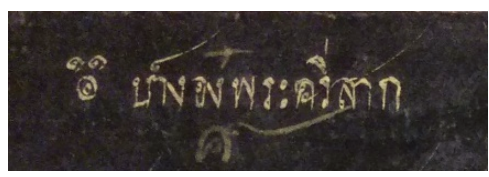

Fig. 1: Example of corrections between the lines: Copenhagen, The Royal Library, Siam 4, Volume I, recto 9; (c) Copenhagen, The Royal Library.

This way of making corrections appears to have been quite common in almost every genre of Siamese manuscripts and can even be traced back to the epigraphic evidence of the Sukhothai kingdom, as it also appeared in the 'Pa Nang Mò Inscription' (inscription no. 288) dated between 1392 and 14047. In this inscription (Fig. 2), a mistake has been crossed out and marked with a cross (+) below it, while the new words have been written in the following line, indicated by the cross at the beginning of the line.

7 Fine Arts Department 2005, 185. 

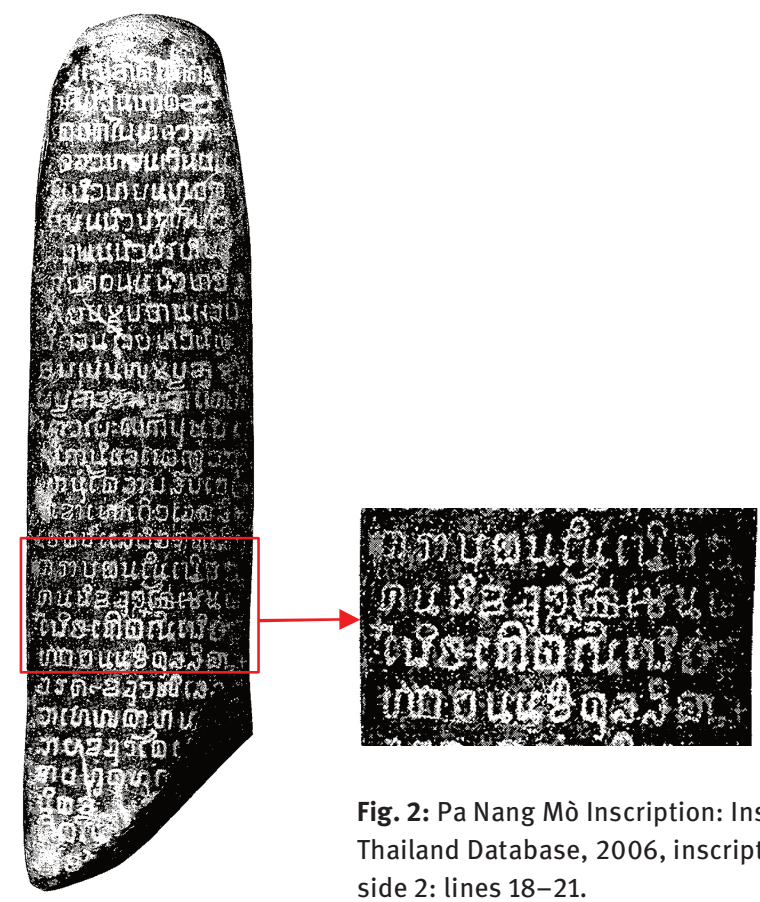

Fig. 2: Pa Nang Mò Inscription: Inscriptions in Thailand Database, 2006, inscription no. 288: side 2: lines 18-21.

Besides containing corrections added between the lines, some manuscripts also include glosses written between the lines, although these are not as frequent. In most cases, glosses were added by readers who wrote down the meaning of archaic words or interpreted more complex sections of the text. It can be argued that there was no tradition of writing separate commentaries to any complete vernacular Siamese text until the late nineteenth century, unlike the canonical texts in Pali whose commentaries have been transmitted separately, a tradition that can be traced back to India and Lanka many centuries ago. ${ }^{8}$ Glosses in Siamese poetry only occur partially, mainly out of necessity due to nearly unreadable stanzas or archaic words without any other aids to understanding their meaning.

One example of glossing can be found in a manuscript recording the Khlong Lokkanit ('Didactic Poem on Worldly Conduct'), which only contains glosses for some of the most difficult stanzas. The manuscript contains 200 stanzas of the text in all, but glosses are only provided for four of them (nos 72, 84, 156 and 176). The interlinear gloss in this manuscript begins at the space below the last line of

8 For more details, see Hinüber 2000, 100-153. 
the stanza and continues into the right margin of the page. The example below (Fig. 3) offers an interpretation or a paraphrase of the last line of stanza no. 156.

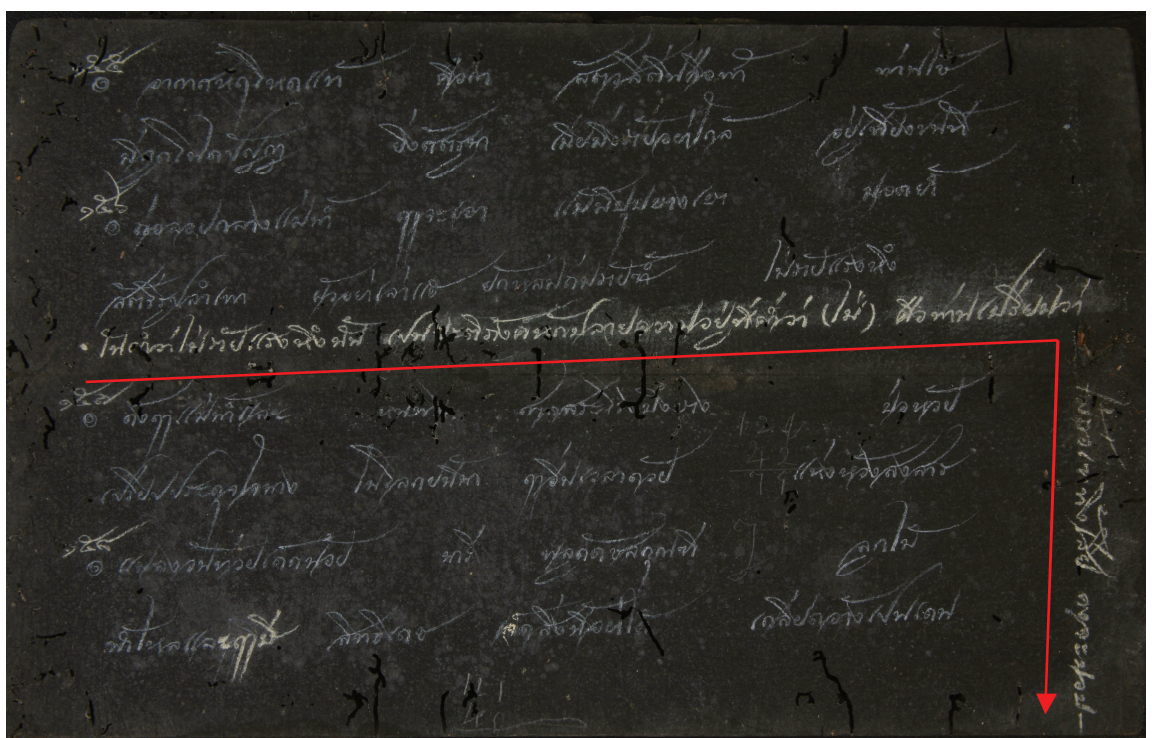

Fig. 3: Glossing of an interpretation of the text found in the manuscript of Khlong Lokkanit: National Library of Thailand, Khlong Suphasit Subsection, MS no. 106, verso 26-30; (C) National Library of Thailand.

The stanza in the manuscript of Khlong Lokkanit (Fig. 3) and its English translation: ${ }^{9}$

$\begin{array}{ll}\begin{array}{ll}\text { ถ่อลอยกลางแม่น้ำ } \\ \text { แม้มิบุบบางเบา }\end{array} & \begin{array}{l}\text { ฤาจะเอา } \\ \text { สัตรีรูปลำเภา } \\ \text { ยักหล้ำ } \\ \text { ผัวหย่า เล่าแฮ } \\ \text { ไม่ร้ายแรงหึ่ง }\end{array} \\ \begin{array}{ll}\text { Thò lòi klang mae nam } \\ \text { Mae mi bup bang bao } \\ \text { Satri rup lam phao }\end{array} & \begin{array}{l}\text { rü ca ao } \\ \text { mòt yam } \\ \text { phua ya lao hae }\end{array}\end{array}$

9 Most of the English translations of Thai literary texts in this article have been done by me, except for Yuan Phai, whose English translation done by Baker and Phongpaichit (2017) is available. When cited the English translation from other publications, its source will thus be given as a reference. 
Yak lom thom rai sam

mai rai raeng hüng

A pole floating in mid-river should not be taken,

[because] it is either too light or it has been eaten [i.e. damaged] by the red flour beetle.

A divorced woman, no matter how beautiful she is, [cannot be taken either,]

[because] one would be inauspicious or she would be too jealous.

The Gloss in the same manuscripts reads as follows:

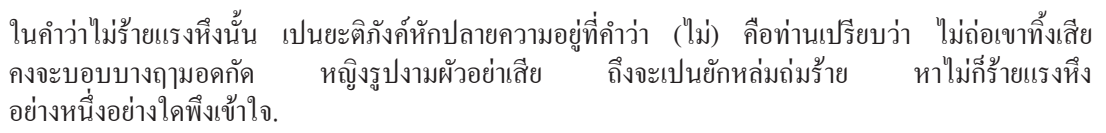

Transliteration and translation:

nai kham wa mai rai raeng hüng nan pen yatiphang hak plai khwam yu thi kham wa (mai) khü than priap wa mai thò khao thing sia khong ca bòp bang rü mòt kat ying rup ngam phua ya sia thüng ca pen yak lom thom rai ha mai kò rai raeng hung yang dai yang nüng phüng khao cai

In the expression mai rai raeng hüng there is a punctuation mark after the word mai. The stanza concerns a wooden pole which has been thrown away or abandoned, either because it was too light or it had been eaten away by a beetle. In the same way, a beautiful woman who is divorced cannot serve as a support, as one would be inauspicious or troubled by her jealousy. ${ }^{10}$ One should understand [the stanza this way].

This manuscript is the only one out of 27 to have preserved the same version of the text and its glosses. The explanation above may have been added by the anonymous owner of the manuscript. Apparently, the main text had been copied completely before the glosses were added, as there is very little space left for the glosses. Furthermore, the handwriting and the writing substance - in this case white steatite pencil - look slightly different to the main text. Only four stanzas have been annotated in this manuscript; these were considered too obscure to be interpreted by the scribe or the owner. Although the text mentioned above has been partially annotated, the glosses reveal how traditional readers understood the text. Thus, we can assume that a gloss of this kind was not a standard one and was probably added by a reader to help him understand the text. Only by looking more closely at these kinds of interlinear notes can we get any idea of how educational texts were analysed by the reader beyond what has been passed

10 In traditional Siamese culture, which is male-dominated, a divorced woman is often blamed for her jealousy, as a Siamese male tends to have several spouses at the same time. This didactic poem undeniably reflects the bias against women in the traditional polygynous society. 
on in canonical form from one generation to the next. Thus, the glosses should be regarded as an important source of information on how knowledge about each stanza was transmitted and not just as a way of explaining archaic or foreign words used in a text.

\section{Annotating archaic and foreign words}

The manuscripts examined here contain extended glosses, which are limited to the old poetry and mainly explain the meaning of obscure words. Earlier poetry transmitted from the kingdom of Ayutthaya (1351-1767) always contains obsolete words, either archaic Thai words or loanwords from Pali, Sanskrit or Khmer. These three languages strongly influenced the literary language of the Siamese and the colloquial language used today. The loanwords from these languages have been used for poetic beauty, simultaneously signifying the higher levels of education and skills of the poet. In addition, texts which have been adapted or translated from foreign literature, such as Buddhist Jataka tales or Sanskrit epics, tend to use loanwords as well. It is thought that the pleasure that traditional Siamese readers gained in reading old poetry came from an appreciation of the poet's eloquence and the poetic embellishment of his thoughts rather than from the story narrated in the text, which was widely known from oral tradition anyway ${ }^{11}$. Readers of old Siamese poetry in the pre-modern period must therefore have had some knowledge of these foreign languages.

Nonetheless, many loanwords must have already been considered obsolete when the old texts were transmitted to the Bangkok period, seeing as the texts needed to be annotated while they were being read and studied. In most cases, readers recorded the meaning of archaic words as interlinear glosses in their own manuscripts, perhaps as a reminder to themselves when reading the text.

One particular manuscript with glosses of archaic words contains The Collection of Old Elephant Treatises. This work compiles three different poems from the kingdom of Ayutthaya concerning the elephant ceremony performed at the royal palace. Two of these texts are believed to have been recited at a ceremony in the Ayutthaya period. The texts are considered models of the ceremonial elephant treatises written in the Bangkok period. Dozens of manuscripts preserving this

11 Eoseewong 2005, 12. 
collection of texts have survived. The language of these old poems on the elephant ceremony has clearly been influenced by Old Khmer and Sanskrit. ${ }^{12}$ The particular manuscript ${ }^{13}$ referred to here has impressively preserved the annotations about obscure words, especially in the initial part of the text, and also contains comments and corrections in certain parts. While the main text has been written in yellow ink in neat, uniform handwriting, the glosses are in scribbled handwriting in a white steatite pencil. The handwriting used for the glosses throughout this manuscript looks consistent enough to have been added by one particular person rather than several different users.

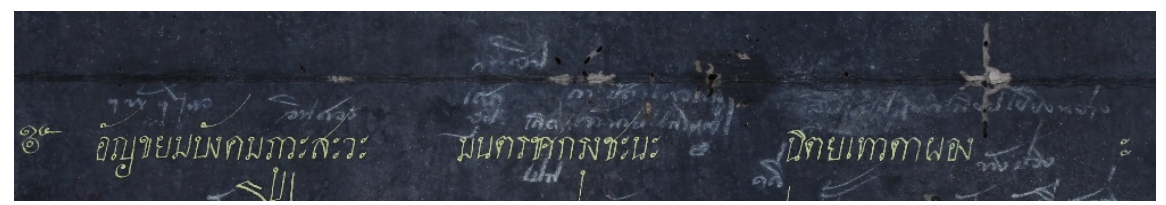

Fig. 4: An example from The Collection of Old Elephant Treatises with glosses annotating some obscure loanwords: National Library of Thailand, Chan Subsection, MS no. 16, recto 5; (c) National Library of Thailand.

The main text (Fig. 4) is written in yellow ink (highlighted in the transcriptions below), while the glosses are written in white steatite pencil:

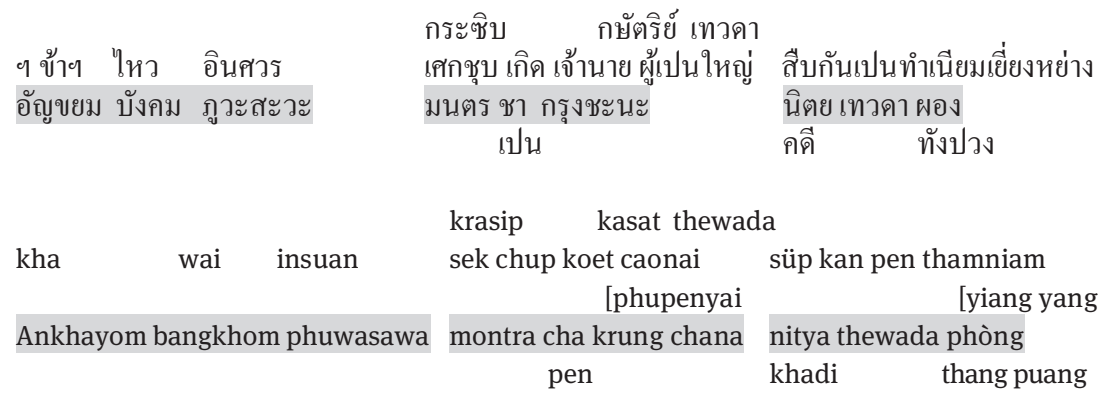

12 Santi Pakdeekham (2004a, 125) even points out that the beginning of the text (the part called Dutsadi Sangwoei) may have been taken directly from an earlier Khmer poem rather than being composed by the Siamese poet Khun Thepkawi as it contains so many Khmer words and Sanskrit loanwords in Khmer; the influence of the Thai language is less prominent here, unlike the other parts of the text.

13 National Library of Thailand, Chan Subsection, MS no. 16. 
whispering kings, deities
I worship Lord Shiva
casting spells emerge royalties, lords long practiced as a tradition
I revere Phuwasawa, whose power is over the lords and the long worshipped gods entirely.
$\begin{array}{cccc}\text { be } & \text { way all }\end{array}$

In the stanza above, all the words used are Khmer and Sanskrit. Consequently, practically all of them have been annotated to help the reader understand the stanza better, except for the word thewada ('god'), which was widely known and used in the Siamese language. It seems that the person who wrote these glosses was a scholar with considerable knowledge of ancient languages, royal ceremonies and elephant lore. Unfortunately, we do not have any information on the commentator of this manuscript, which the National Library of Thailand says was donated in 1908 by Mòm Phaichayonthep or Mòm Ratchawong Phin Sanitwong (1870-1916), whose grandfather was Prince Wongsathirat Sanit (1808-1871), a prominent scholar in the mid-nineteenth century. This manuscript therefore seems to have been in the possession of this princely family at some point. The glosses it contains may have been added under the supervision of a scholar from the family or were possibly even added by Prince Wongsathirat Sanit himself.

Another text that required glosses is a poetic travelogue called Nirat Hariphunchai ('A Poetic Travelogue for Hariphunchai'), which was originally written in the Lan Na Tai language sometime between the fifteenth and seventeenth century. ${ }^{14}$ It was then translated into Siamese and adapted. ${ }^{15}$ Although Lan Na Tai or Kam Müang, the language spoken in the Lan Na Kingdom in the upper north of Thailand, belongs to the same linguistic family as Siamese and Thai, many Lan Na Tai words used in this poem can be considered foreign to Siamese readers, while some Pali loanwords used in the text are in the forms adapted in the Lan Na language. Two of the four extant manuscripts of this text therefore contain different glosses, annotating obscure words - mostly the Lan Na Tai words and the Pali loanwords in the Lan Na Tai language.

The examples below both indicate the same stanzas of the Nirat Hariphunchai from two different manuscripts ${ }^{16}$. Although the same words have been glossed in some cases, the two manuscripts generally contain annotations about different words.

14 See the discussion of its dating in Lagirarde 2004.

15 See the comparison between two versions in Prasert Na Nagara 2004.

16 National Library of Thailand, Khlong Nirat Subsection, MSS nos 402 and 405. 


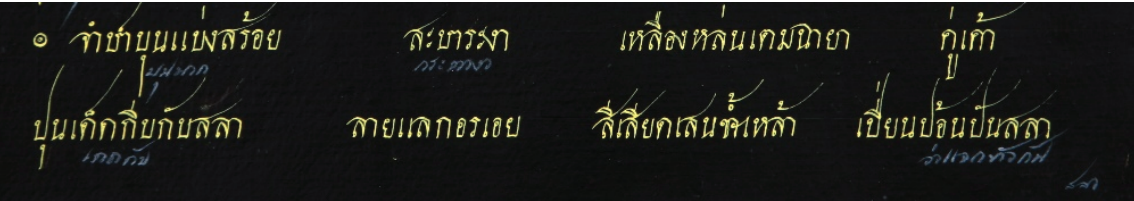

Fig. 5: An example of the glosses from a manuscript of Khlong Nirat Hariphunchai (stanza no. 38): National Library of Thailand, Khlong Nirat Subsection, MS no. 402, recto 23;

(c) National Library of Thailand.

Transcription and translation:

จำปาบุนแบ่งสร้อง
บุนนาก
เหลืองหล่นเตมฉายา
ปุนเด็ดกีบกับสลา
เดดกัน
สีเส้ยดเสนซ้าเหล้า

Campa bun baeng sòi bunnak

Lüang lon tem chaya

Pun det kip kap sala det kan

$$
\begin{aligned}
& \text { สะบาระงา } \\
& \text { กระดังงา } \\
& \text { คู่เค้า } \\
& \text { ลายแลก อรเอย } \\
& \text { เปี่ยนป้อนปันสลา } \\
& \text { ว่าแจกข้าวกัน }
\end{aligned}
$$

sabaranga kradang-nga

khu khao

lai laek òn oei

Si siat sen sam lao pian pòn pan sala wa caek khao kan

The flowers of Champa and Bunnak are blooming together with Sabaranga,

$$
\text { Indian rose chestnut }
$$

ylang-ylang tree

and all their yellow petals will fall off together.

I would like to pluck the flowers and chew betel with you, my darling! pluck [flowers] together

I yearn for the moment we are close and can give each other with the Sala. means giving rice to each other 


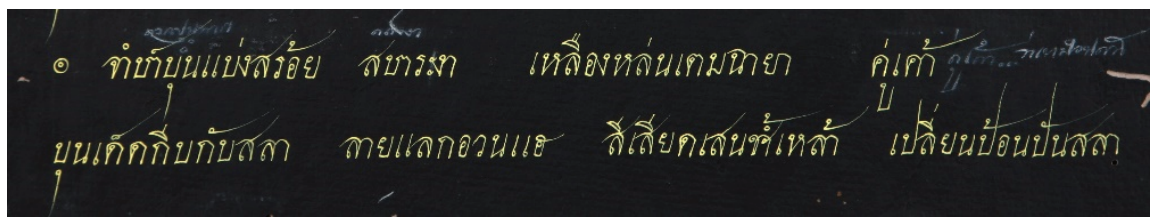

Fig. 6: Another manuscript of Khlong Nirat Hariphunchai with glosses, this part contains the same stanza as the previous figure (stanza no. 38), but the glosses are different: National Library of Thailand, Khlong Nirat Subsection, MS no. 405, recto 23; (c) National Library of Thailand.

Transcription and translation:

\begin{tabular}{|c|c|}
\hline จำปาบุนแบ่งสร้อย & สบาระงา \\
\hline $\begin{array}{c}\text { ดอกบุนนาก } \\
\text { เหลืองหล่นเตมฉายา }\end{array}$ & $\begin{array}{l}\text { กดงงา } \\
\text { คู่เค้า } \\
\text { คู่เค้า ... ว่าคู่กัน }\end{array}$ \\
\hline $\begin{array}{l}\text { บุนเด็ดกีบกับสลา } \\
\text { สี่เสียดเสนซ้ำเหล้า }\end{array}$ & $\begin{array}{l}\text { ลายี่เลก อรเอย } \\
\text { เปลี่ยนป้อนปันสลา }\end{array}$ \\
\hline $\begin{array}{l}\text { Campa bun baeng sòi } \\
\text { dòk bunnak }\end{array}$ & $\begin{array}{l}\text { sabaranga } \\
\text { kadang-nga }\end{array}$ \\
\hline Lüang lon tem chaya & $\begin{array}{l}\text { khu khao } \\
\text { khu khao... wa khu kan }\end{array}$ \\
\hline $\begin{array}{l}\text { Bun det kip kap sala } \\
\text { Si siat sen sam lao }\end{array}$ & $\begin{array}{l}\text { lai laek òn oei } \\
\text { pian pòn pan sala }\end{array}$ \\
\hline
\end{tabular}

The flowers of Champa and Bunnak are blooming together with Sabaranga, flower of Indian rose chestnut ylang-ylang tree and all their yellow petals will fall off together. together ... means being with each other

I would like to pluck the flowers and chew betel with you, my darling! I yearn for the moment we are close and can give each other with the Sala.

In the examples above, the glosses from these two manuscripts are not identical, although the words bun and sabaranga - the names of flowers in the Lan Na Tai language - are glossed in both manuscripts. The other glosses in the two manuscripts have been added for different words, suggesting they were annotated by at least two different people. It may be argued that the text was read and studied by different groups of people, even though it has not survived in many manuscripts.

A more obvious case of a foreign text in Siamese manuscripts which needed glossing in order to facilitate its reading is that of the Kham Phak Ramakian-The 
Khmer Version or 'Poetic Script of the Ramayana Epic in the Khmer Language'. The text has survived as fragments in just four manuscripts, ${ }^{17}$ each of which has preserved different chapters of it. The text is undoubtedly monolingual Khmer, but it was written in a rough transcription in Thai script in the late eighteenth century..$^{18}$ Perhaps this was transcribed into Thai because the text had to be recited during a khon performance at the Siamese royal court and the reciter was not able to read it in Khmer script. This text is a unique case in which a piece of Khmer performance poetry in Thai script has survived in Siamese manuscript culture; this has consistently been explained as being the result of the connection between the royal elites of Siam and Khmer in the early Bangkok period. In the late eighteenth century, some Khmer princes and other members of the royal court went into exile in Bangkok while civil war was raging in their country. As a scribal colophon suggests that a manuscript of the text originated in a royal environment, this text in Thai script may have been transmitted among the members of the Siamese royal court of Bangkok ${ }^{19}$, where the Khmer khon was performed. The text was originally written and recited in the Khmer language, so it was not readily intelligible to the Siamese, thus making the glosses on Khmer words necessary. These glosses written in handwriting that differs from that of the main text appear to have been added by an expert in the Khmer language from the Siamese royal court.

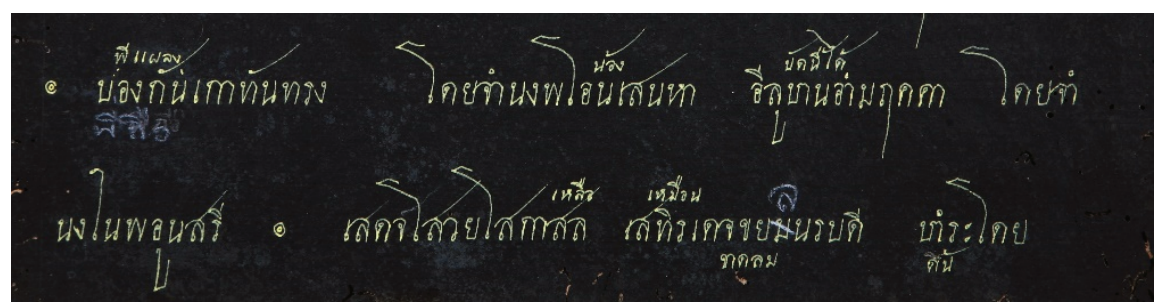

Fig. 7: A manuscript of Kham Phak Ramakian - The Khmer Version with interlinear glosses written in small letters: National Library of Thailand, Khlong Subsection, MS no. 165, verso 13; (c) National Library of Thailand.

17 National Library of Thailand, Kham Phak Subsection, MSS nos 57, 58, 59, and Khlong Subsection, MS no. 165.

18 Santi Pakdeekham 2004b, 20; See Pou 1979 for the Khmer text of the same chapter.

19 Santi Pakdeekham 2004b, 2. 
Transcription and translation:

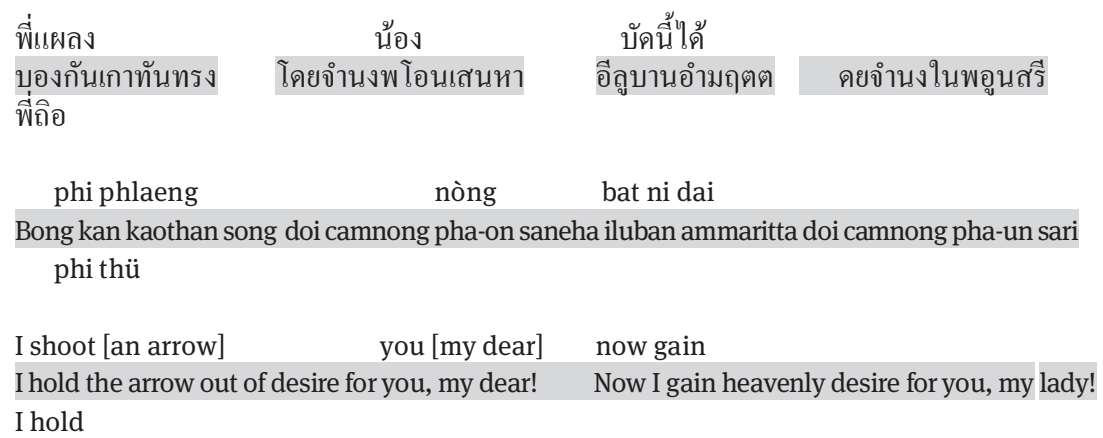

The glosses do not provide full translations of any of the stanzas, though, probably because the explanations of the obscure words were sufficient for the Siamese readers to make sense of the text; the words that were not glossed were used in Siamese and were therefore considerably easier for Siamese readers and speakers to understand despite their Khmer origin. The examples of the archaic and foreign poetry given above pertain to the extended glosses appearing in manuscripts of classical Siamese poetry, which have been added by an individual rather than being copied to uphold a further tradition. The only case in which transmitted glosses have been found in Siamese poetry is a manuscript containing the Yuan Phai, a royal eulogy from the kingdom of Ayutthaya.

\section{The glossing tradition of Yuan Phai: a single case of the archaic royal eulogy}

Yuan Phai, or literally 'The Defeat of the [Tai] Yuan [of Lan Na]', is one of the most complex royal eulogies ever written in Siamese. The text, originally written around the fifteenth century, focuses on the victory of King Trailokkanat of Ayutthaya (r. 1448-1488) in the war against the kingdom of Lan Na (known as 'Yuan') in 1474. It begins with words of praise for King Trailokkanat, employing complicated foreign words and literary allusions to Buddhist texts, Hindu mythology and the Sanskrit epics Mahābhārata and Rāmāyaṇa. The text, significantly, provides historical information and also represents the most complicated of literary arts in Siamese poetry. Yuan Phai was widely transmitted during the Bangkok period, influencing the poetry of Bangkok as a model for royal eulogies. However, the beginning of the text, embellished with complex figures of speech, 
is considered to be so complicated and hard to understand that most readers give up reading it and never get round to appreciating the remaining part of the text $\mathrm{t}^{20}$. The anonymous author was a great poet and scholar of the period, and readers of the text consequently require a considerable amount of knowledge about foreign words, Buddhist texts and Sanskrit epics in order to understand Yuan Phai properly, especially the initial part of the text.

There are twenty stanzas in this literary work that are particularly complicated and they all occur in a row: nos 12-32. These all play on the repetition of Pali and Sanskrit numerals from one to ten to describe the various prestigious characteristics and abilities the King possesses. For instance, stanza no. 17 employs the repetition of the Sanskrit word for 'four' (Skt: catur) to describe the King's knowledge in different categories of four, as shown below:

\begin{tabular}{|c|c|}
\hline $\begin{array}{l}\text { จตุรมัคยลโยคแจ้ง } \\
\text { แจेงจตุรพรรณ }\end{array}$ & $\begin{array}{l}\text { จตุรพิทธ เพรอศแฮ } \\
\text { พ่อเลียง }\end{array}$ \\
\hline $\begin{array}{l}\text { จตุรพุทธทิศ } \\
\text { แจ้งจตุรพักตร์เพี้ยง }\end{array}$ & $\begin{array}{l}\text { จตุรเทศ } \\
\text { พ่างอารย }\end{array}$ \\
\hline Caturamak yon yok caeng & caturaphit phroet hae \\
\hline Caeng caturaphan & lò liang \\
\hline Caturaphut thit & caturathet \\
\hline Caeng caturaphak phiang & phang an \\
\hline
\end{tabular}

An English translation of the stanza by Baker and Phongpaichit ${ }^{21}$ goes like this:

He understands four paths, and four insights.

He knows the fourfold castes and is their patron,

Four weapons and directions, continents,

Four views sublime He knows like noble ones.

A proper understanding of the stanza and the others in this particular part of the work requires a sound knowledge of Buddhist texts for the reader to see what the four paths and four insights refer to, quite apart from knowledge of the foreign words employed throughout the stanzas. In some of the manuscripts, glosses have been added to these twenty stanzas to explain the different categories in more detail and explain the meaning of archaic words.

Seven of the twenty-four extant manuscripts of Yuan Phai which are currently preserved at the National Library of Thailand contain glosses for these twenty

20 Baker and Phongpaichit 2017, 2.

21 Baker and Phongpaichit 2017, 21. 
stanzas. Furthermore, the glosses show the same content and wording in all seven manuscripts, albeit with some variant spellings, suggesting a common origin. Apparently, the scribes always left some space under each quarter of a stanza (or 'bat' in Thai) for lengthy glosses, which indicates that they realised that an explanation was called for and therefore 'planned ahead' by leaving enough blank space for adding such glosses. In most of these manuscripts, the handwriting and writing substance seem to be identical in both the main text and the glosses, although the glosses are a little smaller in size sometimes, probably in order to save writing space and distinguish the glosses from the main text. The example below shows the glosses for stanza no. 17, in which the meaning of each of the four categories is clarified:

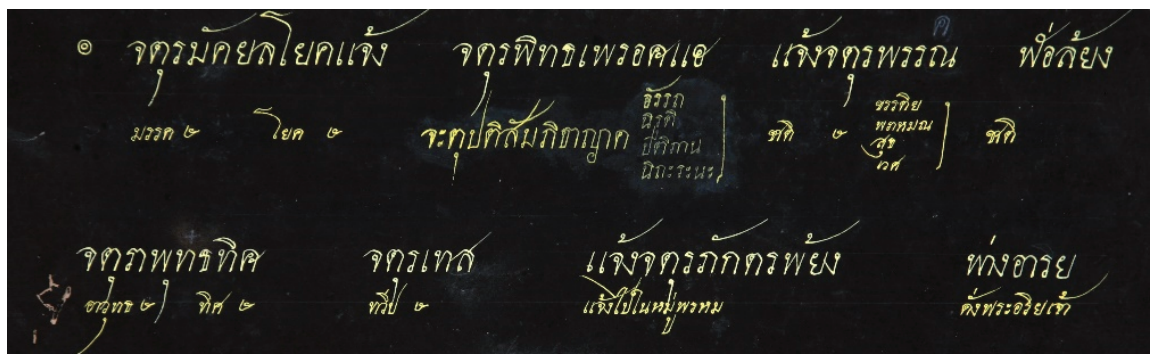

Fig. 8: A manuscript of Yuan Phai with glosses between the lines, this part bears the text of stanza no. 17: National Library of Thailand, Lilit Subsection, MS no. 188, recto 20; (c) National Library of Thailand.

Transcription and translation:

จตุรมัคยลโยคแจ้ง
มรรค ๔ โยค ๔

แจ้งจตุรพรรณ
ชาติ ๔ ขรรติย ชาติ
พราหมณ
สุธ
เวศ

จตุรพิทธ เพรอศแฮ จะตุปติสัมภิธาญาต อัรรถ

$$
\text { นิรุติ }
$$

ปติภาน

นิถะระนะ

พ่อเลี้ยง 


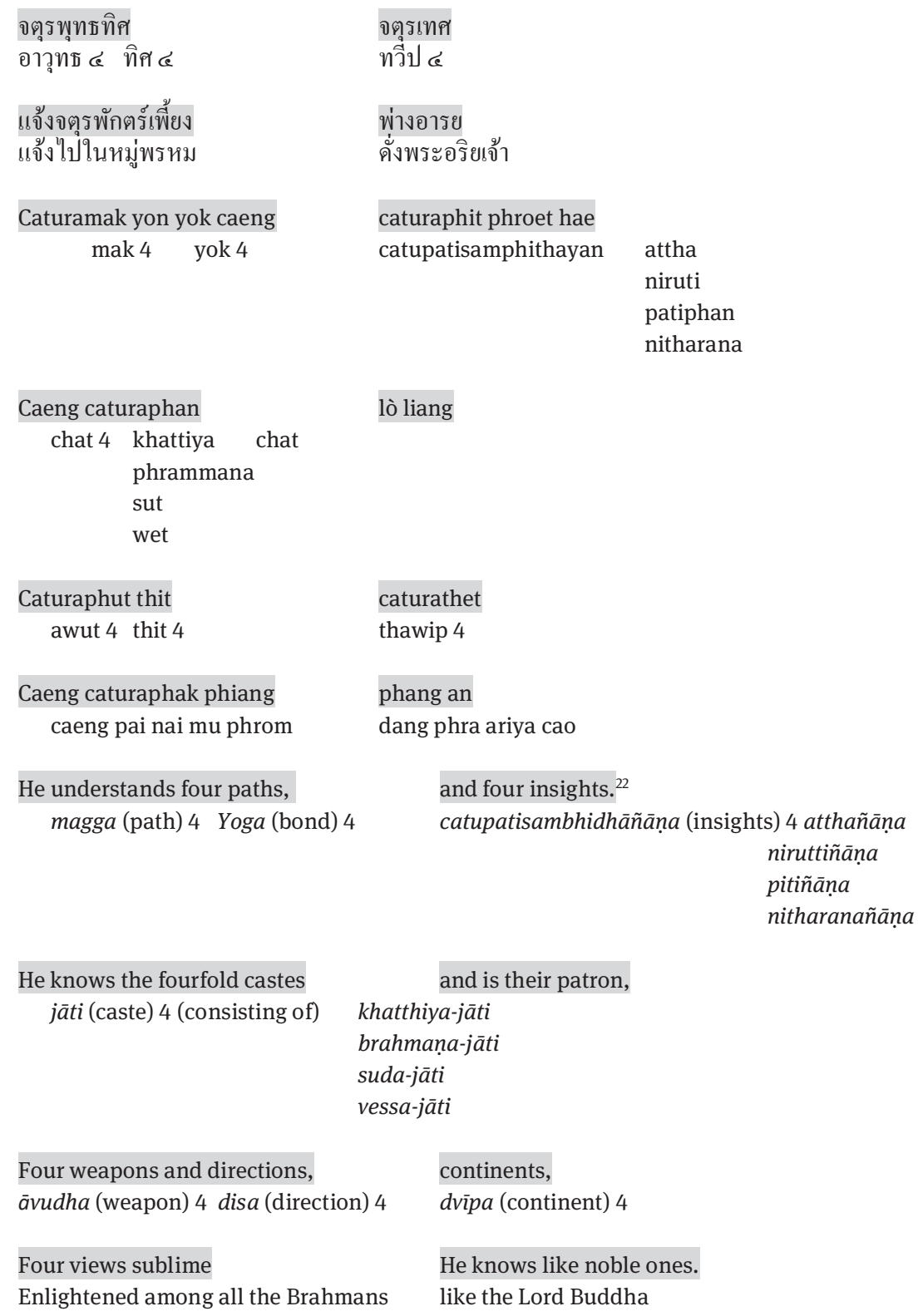

22 The translation of this stanza comes from Baker and Phongpaichit 2017, 21, while the translation of the gloss belongs to me. 
Although the glosses were not always copied together with the main text in all the extant manuscripts, common glosses do appear in significant numbers - on roughly a third of the manuscripts. The identity of the commentators who originally wrote the glosses is unknown. Still, according to the National Library's acquisition history and the opinion of scholars in the late nineteenth century, these manuscripts once belonged to the royal palace's manuscript collection, implying that the glosses were written at the royal court of Bangkok ${ }^{23}$.

Glosses were not always simply copied along with the main text without any further additions being made. In MS no. 196, for instance, which is one of seven manuscripts containing an annotated version of Yuan Phai, other stanzas have been glossed as well, not just stanzas 12-32. The scribe prepared the space for these twenty stanzas, but glosses for other stanzas were simply added between the lines. Perhaps the commentator adopted the transmitted glosses of these twenty stanzas in this particular manuscript and then added further glosses of his own to some of the other stanzas. As the manuscript was originally from the monastery of Wat Molilok (in present-day Bangkok), Yuan Phai will have been transmitted and read by members of this Buddhist monastery as well, and in this case, the commentator may have been monk-scholars based at Wat Malilok.

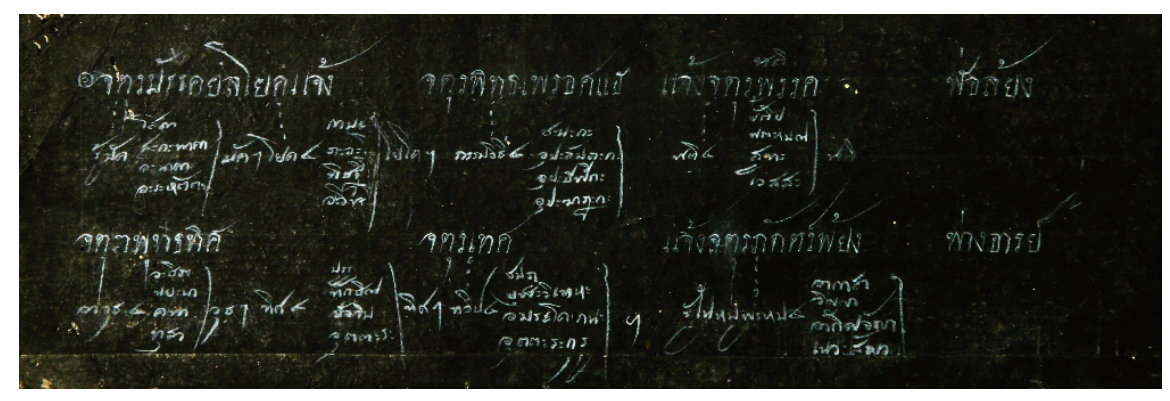

Fig. 9: The glosses of stanza no. 17 from manuscript 196, indicating the same glosses in other manuscripts, but in more detail: National Library of Thailand, Lilit Subsection, MS no. 196, recto 21; (c) National Library of Thailand.

23 Santi Pakdeekham 2007, 2-3. 


\section{Transcription and translation:}

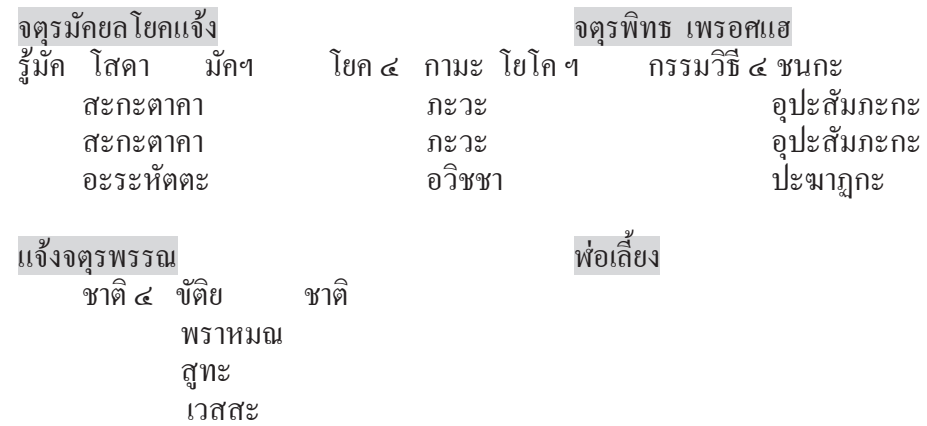

แจ้งจตุรพักตร์เพี้ยง

พ่างอารย

รู้ในหมู่พรหม ๔ อากาสา

$$
\begin{aligned}
& \text { วิญญา } \\
& \text { อากิญจัญา } \\
& \text { เนวะสัญญา }
\end{aligned}
$$

\begin{tabular}{ccc} 
Caturamak yon yok caeng & \multicolumn{2}{c}{ caturaphit phroet hae } \\
ru mak 4 soda mak & yokha 4 kama yokho & kammawithi 4 chanaka \\
sakatakha & phawa & upasamphaka \\
anakha & thitthi & upapilaka \\
arahatta & awitcha & upakhataka
\end{tabular}

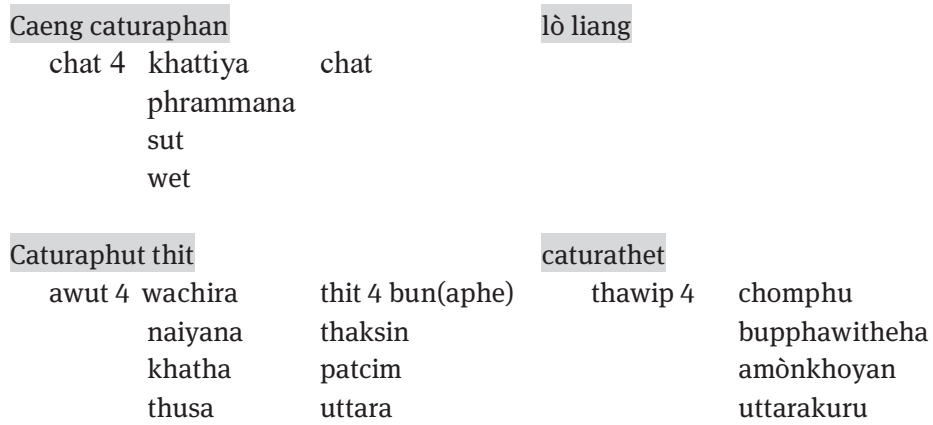




$\begin{array}{cl}\text { Caeng caturaphak phiang } & \text { phang an } \\ \text { ru nai mu phrom } 4 & \text { akasa } \\ & \text { winya } \\ & \text { akincanya } \\ & \text { newasanya }\end{array}$

He understands four paths, and four insights. ${ }^{24}$

Magga (path) 4 sotā-magga Yoga (bond) 4 kāma-yoga Kammavidhi (method of deed) 4 [janaka-vidhi

$\begin{array}{lll}\text { sagatāgā-magga } & \text { bhava-yoga } & \text { upasambhaka-vidhi } \\ \text { anāgā-magga } & \text { dițthi-yoga } & \text { upapillika-vidhi } \\ \text { arahatta-magga } & \text { avijja-yoga } & \text { upaghațaka-vidhi }\end{array}$

He knows the fourfold castes and is their patron, $J \bar{a} t i$ (caste) 4 (consisting of) khatthiya-jāti

brahmana-jāti

suda-jāti

vessa-jāti

Four weapons and directions, continents,

āvudha (weapon) 4 vajïāvudha disa (direction) 4 pubba-disa dvīpa (continent) 4 [jambu-dvīpa nayanāvudha dakkhina-disa pubbavideha-dvīpa gadāvudha paccima-disa amaragoyāna-dvīpa dusāvudha uttara-disa uttarakuru-dvīpa

\author{
Four views sublime He knows like noble ones. \\ Wise among 4 [types of] Brahmans ākāsā-brahma \\ viñ̃̃̄a-brahma \\ ākiñcaññā-brahma \\ nevapasañ̃ā-brahma
}

24 The translation of this stanza comes from Baker and Phongpaichit 2017, 21, while the translation of the gloss belongs to me. 


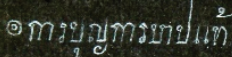 \\ 1 \\ ถ่ากักถรดกบร \\ ทกเทคกัก \\ S

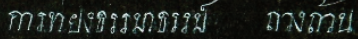 \\ S 1

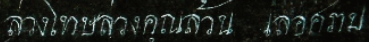

Fig. 10: An example of glosses added to another stanza (no. 49), which does not appear in any other manuscript with interlinear glossing. Thus, this glossing has been added by the commentator; National Library of Thailand, Lilit Subsection, MS no. 196, recto 46; ( N National Library of Thailand.

\section{Transcription and translation:}

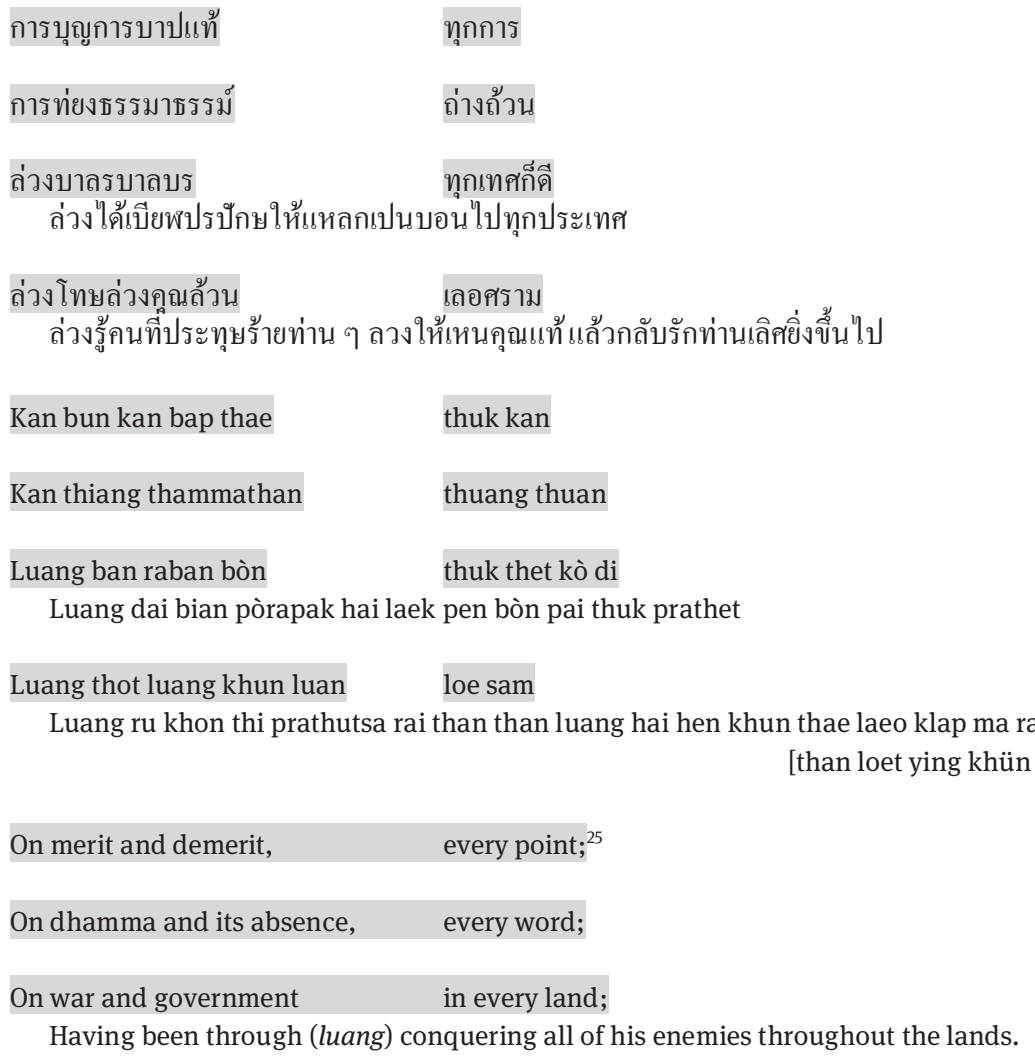

25 The translation of this stanza comes from Baker and Phongpaichit 2017, 30, while the translation of the gloss belongs to me. 
On virtue and on vice; $\quad$ his grasp is firm.

Knowing all (luang ru) the one who hates him, he shows them the true virtues that

[make them love him.

Yuan Phai is the only piece of Siamese poetry that appears to have been transmitted together with glosses, which is no doubt due to its highly complex language and style. Furthermore, it is also the first Siamese poem to have been 'translated' (or in this case paraphrased) entirely into modern Thai in the form of a separate piece of commentary ${ }^{26}$. At least two versions of the commentary on Yuan Phai from the late nineteenth century have survived: 'A Prose Version of Yuan Phai' (1887) and 'A Translation of Yuan Phai' (1888). Both were written by the same author, Phra Ubali Khunupamacan (Pan) (1828-1904), who was the abbot of Wat Phra Chetuphon Monastery and a prominent scholar and poet in the late nineteenth century. The first commentary, 'A Prose Version of Yuan Phai', presents a paraphrase of the text in prose, while the latter records the main text parallel to the translation of each word or line. Phra Ubali Khunupamacan must have consulted the glosses in a manuscript as well, given that some of the explanations correspond to the transmitted glosses found in the manuscripts (albeit imperfectly). Late nineteenth-century readers (and scholars) may have felt that a complete translation was necessary, not just those found in the twenty stanzas. Yuan Phai has become a unique case in Siamese literature, displaying the practice of manuscript glossing and writing separate commentaries.

\section{Concluding remarks}

According to manuscript evidence, the glossing of literary texts was not a common practice in Siamese manuscript culture. This can be deduced from the fact that very few manuscripts have survived that contain glosses, and those that have are limited to a group of archaic texts requiring a refined understanding of the language and content. In the case of Yuan Phai with its poetic eloquence and the case of Kham Phak Ramakian - The Khmer Version, which was transcribed into Thai, the texts may have been impossible for Siamese readers from the traditional period to read and understand had it not been for the explanatory glosses that were added. Despite the fact that the number of glossed extant manuscripts is small, the glosses should nonetheless be considered significant evidence of the study of Siamese manuscript culture and historical Thai literature.

26 Santi Pakdeekham 2007, 3. 
The surviving glosses indicate how the readers engaged actively with their manuscripts and that readers and/or scholars were at work there, probably for purposes of their own, but also partly to explain certain key terms to future generations of readers. In the unique case of Yuan Phai, the glosses that were made originally were replicated in manuscript copies over the course of time. These manuscripts do not just serve as carriers of texts, but also as carriers of traditional knowledge, namely, textual scholarship. For modern scholars, glosses not only help us to gain a better understanding of a text's meaning in terms of its ancient vocabulary or encrypted stanzas, for example, but they also give us a better understanding of the textual meaning in the past since they are evidence of scholarly reflection on the dynamic learning tradition associated with that particular piece of writing. They give us an idea of how traditional readers and scholars made sense of difficult passages in the texts and show us how they employed manuscripts as a tool for recording their own learning, even if they just regarded such glosses as personal notes rather than reflections on common interpretations. With respect to traditional Siamese education in particular, in which an oral tradition predominated, these glosses have become a rare piece of written evidence of the traditional textual scholarship that once existed in nineteenthcentury Thailand and are a part of Siamese manuscript culture which should be further examined and appreciated.

\section{References}

Baker, Chris (2002), 'From Yue to Tai', Journal of the Siam Society, 90/1-2: 1-26.

Baker, Chris and Pasuk Phongpaichit (2017), Yuan Phai, The Defeat of Lan Na: A Fifteenth-Century Thai Epic Poem, Chiang Mai: Silkworm Books.

Brun, Viggo (1990), 'Traditional Manuals and the Transmission of Knowledge in Thailand', in Birthe Arendrup, Simon B. Heilesen and J. Ø. Petersen (eds), The Master Said: To Study and... To Søren Egerod on the Occasion of His Sixty-Seventh Birthday, Copenhagen: East Asian Institute, University of Copenhagen, 43-66.

Eoseewong, Nidhi (2005), Pen \& Sail: Literature and History in Early Bangkok, Chiang Mai: Silkworm Books.

Fine Arts Department กุรมศิลปากร (2005), Prachum Carük Phak Thi 8: Carük Sukhothai ประชุมจารึก ภาคที่ $\approx$ จารึกสุโขทัย, Bangkok: Fine Arts Department, Ministry of Cultures. Hinüber, Oskar von (2000), A Handbook of Pāli Literature, Berlin: De Gruyter. Inscriptions in Thailand Database ฐานข้อมูลจารึกในประเทศไทย (2006), Carük Pa Nang Mò Inscription จารึกป้านางเมาะ, <http://www.sac.or.th/databases/inscriptions/inscribe detail.php?id=36> (accessed on 10 Jan. 2018).

Kongkaew Weeraprachak ก่องแก้ว วีระประจักษ์ (2010), Kan Tham Samut Thai Lae Kan Triam Bai Lan การทำสมุดไทยและการเตรียมใบลาน, Bangkok: Fine Arts Department. 
Lagirarde, François (2004), 'Un pèlerinage bouddhique au Lanna entre le XVI ${ }^{\mathrm{e}}$ et le XVII siècle d'après le Khlong Nirat Hariphunchai', Aséanie. Sciences humaines en Asie du Sud-Est, 14: 69-107.

Pariyat Thammathada, Phraya ปริยัติธรรมธาดา, พระยา (1972), Boransüksaโบราณศึกษา, Bangkok: Sammit Printing House.

Pipada Youngcharoen and Suwadee Tanaprasitpattana พิพาดา ยังเจริญ และสุวดี ธนประสิทธิ์พัฒนา (1982), Kan Süksa Lae Phon Krathop Tò Sangkhom Thai Samai To Rattanakosin (Phò Sò 2325-2394) การศึกษาและผลกระทบต่อสังคมไทยสมัยต้นรัตนโกสินทร์ (พ.ศ.๒๓๒๕-๒の๕๔), Bangkok: Chulalongkorn University.

Pou, Saveros (1979), Rāmakerti (XVle-XVIIe siècles), Paris: EFEO.

Prasert Na Nagara ประเสริฐ ณ นคร (2004), Khlong Nirat Hariphunchai โคลงนิราศหริภุญไชย, Bangkok: Khuru Sapha.

Santi Pakdeekham ศานติ ภักดีคำ (2004a), 'Dutsadi Sangwoei Klòm Chang Khòng Phra Thepkawi: Mum Mòng Phasa Lae Wannakhadi Khamen ดุษฎีสังเวยกล่อมช้างของขุนเทพกวี: มุมมองภาษาและวรรณคดีเขมร', Damrong Wichakan ดำรงวิชาการ 3/5: 111-127.

Santi Pakdeekham ศานติ ภักดีคำ (2004b), “Kham Chi Caeng Kham Phak Ramakian Phasa Khamen Khòng Phu Chamra Ton Chabap คำชี้แจง คำพากย์รามเกียรติ์ภาษาเขมรของผู้ชำระ ต้นฉบับ', in Fine Arts Department กรมศิลปากร, Prachum Kham Phak Ramakian Lem 3: Kham Phak Ramakian Phasa Khamen ประชุมคำพากย์รามเกียรติ เล่ม ๓: คำพากย์รามเกียรติภาษาเขมร, Bangkok: Fine Arts Department, 1-63.

Santi Pakdeekham ศานติ ภักดีคำ (2007), 'Bot Nam บทนำ', in Wat Phra Chetuphon Monastery คณะสงฆ์วัดพระเชตุพน, Yuan Phai Khlong Dan Chabap Plae Lูae Khwam Riang Rüang Yuan Phai Chabap Phra Ubali Khunipamacan (Pan) ยวนพ่ายโ คลงดันฉบับแปลและ ความเรียงเรื่องยวนพ่าย ฉบับพระ อุบาพีคุณูปมาจารย์ (ปาน), Bangkok: Sahadhammik, 1-24.

Thawat Punnothok ธวัช ปุณ โณทก (1995), Wiwatthanakan Nangsü Baep Rian Wicha Phasa Thai วิวัฒนาการหนังสือแบบเรียนวิชาภาษาไทย, Bangkok: Ram Khamhaeng University Press. Wyatt, David K. (1969), The Politics of Reform in Thailand: Education in the Reign of King Chulalongkorn, New Haven: Yale University Press.

Wyatt, David K. (2003), Thailand: A Short History, New Haven: Yale University Press. 
